\title{
Rosiglitazone but not losartan prevents Nrf-2 dependent CD36 gene expression up-regulation in an in vivo atherosclerosis model Y Hernandez-Trujillo $^{\dagger 1}$, F Rodriguez-Esparragon ${ }^{\dagger 1}$, A Macias-Reyes ${ }^{1}$, A Caballero-Hidalgo ${ }^{1}$ and Jose C Rodriguez-Perez*1,2,3
}

\author{
Address: ${ }^{1}$ Research Unit, Hospital Universitario de Gran Canaria Dr. Negrín, Las Palmas de Gran Canaria, Spain, ${ }^{2}$ Nephrology Service, Hospital \\ Universitario de Gran Canaria Dr. Negrí, Las Palmas de Gran Canaria and ${ }^{3}$ Deparment of Medical and Surgical Sciences, Universidad de Las Palmas \\ de Gran Canaria (ULPGC), Las Palmas de Gran Canaria. Spain \\ Email: Y Hernandez-Trujillo - yaridehernandez@hotmail.com; F Rodriguez-Esparragon - frodesp@gobiernodecanarias.org; A Macias- \\ Reyes - amacrey@gobiernodecanarias.org; A Caballero-Hidalgo - acabhid@gobiernodecanarias.org; Jose C Rodriguez- \\ Perez* - jrodperd@gobiernodecanarias.org \\ * Corresponding author †Equal contributors
}

Published: 26 February 2008

Cardiovascular Diabetology 2008, 7:3 doi:10.1/86/1475-2840-7-3

This article is available from: http://www.cardiab.com/content/7///3

(C) 2008 Hernandez-Trujillo et al; licensee BioMed Central Ltd.

This is an Open Access article distributed under the terms of the Creative Commons Attribution License (http://creativecommons.org/licenses/by/2.0), which permits unrestricted use, distribution, and reproduction in any medium, provided the original work is properly cited.
Received: 27 December 2007

Accepted: 26 February 2008

\begin{abstract}
Background: Thiazolidinediones exert anti-inflammatory and anti-oxidative roles and attenuate atherosclerosis by mechanisms partially independent of their metabolizing actions. High doses of angiotensin type I receptor $\left(A T_{\mid} R\right)$ blocker losartan (LST) seem to promote fat cell formation by preserving PPAR $\gamma$ activity.

Methods: C57BL/6] diet-induced atherosclerotic susceptible mice randomly received a normal or a high-fat high-cholesterol (HFHC) diet and were treated with rosiglitazone (RG), LST or a vehicle for 12 weeks.

Results: HFHC was associated with increased PPAR $\gamma$ gene expression without an over regulation of PPAR $\gamma$ responsive genes, whereas RG and LST treatments were found to maintain PPAR $\gamma$ activity without resulting in increased PPAR $\gamma$ gene expression. A better anti-inflammatory and antioxidant profile in mice treated with RG regarding LST was observed in spite of a similar PPAR $\gamma$ preserved activity. Chromatin immunoprecipitation (ChIP) assays revealed that animals under HFHC diet treated with RG showed a significant nuclear factor erythroid 2-like 2 (Nrf2)-dependent down-regulation of the expression of the CD36 gene.

Conclusion: The PPAR $\gamma$ agonist RG exerts antioxidant properties that significantly reduced Nrf2-dependent CD-36 up-regulation in mice under HFHC diet. Because LST treatment was also associated with a preserved PPAR $\gamma$ activity, our data suggests that these RG antioxidant effects are partially independent of its PPAR $\gamma$ metabolizing properties.
\end{abstract}

\section{Background}

Superoxide generation occurs in conditions such as hypertension, hypercholesterolemia, diabetes, and cigarette smoking. Oxidant stress alters many functions of the endothelium which, associated with traditional risk factors, triggers early vascular inflammation and a predisposition to atherosclerosis [1-3]. Low-density lipoproteins (LDLs) are susceptible to oxidative damage. Oxidative 
stress-mediated LDLs modification (ox-LDLs) has a key role in initiation of the atherosclerotic process $[1,4,5]$. OxLDLs are taken up via different scavenger receptors. The CD36 scavenger receptor constitutes the major ox-LDL receptor [6]. Studies employing transgenic and knock-out mice have demonstrated that CD36 is proatherogenic according to observations that targeted disruption of the gene was protective against atherosclerosis [7]. Components of ox-LDL activate peroxisome proliferator-activated receptor $\gamma$ (PPAR $\gamma$ ) resulted in an up-regulation of the CD36 scavenger receptor $[8,9]$.

Thiazolidinediones (TZDs) are PPAR $\gamma$ agonists that improve insulin sensitivity, reduce triglyceride levels and decrease the risk of atherosclerosis in diabetic patients. TZDs also exert direct effects on vascular wall cells [1012]. TZDs treatments inhibit intimal lesions [13], suppress monocyte elaboration of inflammatory cytokines [14], macrophage activation [15], and the expression of cell adhesion molecules [16]. TZDs also increase the mRNA expression of the proatherogenic CD36 gene. PPAR $\gamma$ seems to be determinant in the $\mathrm{CD} 36$ gene regulation as deduced from macrophages derived from mice in which the PPAR $\gamma$ gene has been "floxed out" [17]. However, most authors suggest that the CD36-increasing effects of TZDs might be overwhelmed by the antiatherogenic effects of other factors. Rosiglitazone (RG) is a TZD that possesses several anti-inflammatory properties demonstrating a protective action in regulating atherosclerosis development [18-20].

Nuclear factor-erythroid 2-related factor 2 (Nrf2) is a member of the Cap 'n' Collar family of basic region-leucine zipper transcription factors. Transcription factor Nrf2 is a major regulator of genes encoding phase 2 detoxifying enzymes and antioxidant stress protein in response to electrophilic agents and oxidative stress. Evidence that oxLDLs and some lipid hydroperoxides contained in ox-LDL enhanced nuclear levels of Nrf2 in macrophages has been reported [21]. This increase results in an up-regulation of the scavenger receptor CD36 and antioxidant stress proteins [21]. Thus, Nrf2 appears as an additional transcription factor regulating CD36 gene expression.

Adipocyte differentiation seems to be linked to an improvement of insulin sensitivity [22]. Sharma et al [2325] proposed the hypothesis that blockade of the reninangiotensin system prevents diabetes by promoting the recruitment and differentiation of adipocytes. In vitro studies further demonstrate that several angiotensin receptor blockers or their metabolites induce PPAR $\gamma$ activity and opposite, ligand activated-PPAR $\gamma$ suppressed $\mathrm{AT}_{1} \mathrm{R}$ gene transcription [25-27]. Paradoxically, studies reveal that a moderate reduction of PPAR $\gamma$ activity as observed in heterozygous PPAR $\gamma$-deficient mice, or the Pro12Ala pol- ymorphism in human PPAR $\gamma$ gene, prevent insulin resistance and obesity induced by a high-fat diet [28]. This reduction is thought to occur because PPAR $\gamma$ expression is regulated by nutritional state [29]. Oxidative and inflammatory mediators as those produced in long-term high-fat high-cholesterol (HFHC) diets are known to be inducers of different responses that regulate PPAR $\gamma$ gene activity. The activity of PPAR $\gamma$ can be finely tuned through integration of diverse phosphorylation events [29-32].

The aim of the present study was to show that RG and losartan (LST) treatments preserved the liver PPAR $\gamma$ activity in mice that were fed with a HFHC diet. On the contrary, a loss of PPAR $\gamma$ activity was observed instead of an increase of the PPAR $\gamma$ gene expression in the untreated hypercholesterolemic control mice. Lipid hydroperoxides levels and the relative expression values of the inflammatory mediators inducible nitric oxide synthase (iNOS) and Interleukin-6 (IL-6) genes were diminished in mice treated with RG with respect to LST treated mice. These findings were suggestive of RG additional properties independent of its metabolizing actions. A difference in the CD36 gene expression level between treated groups was observed. Because oxidative stress activates Nrf2 responses and recently has been described as the essential contribution of Nrf2 to the CD36 gene expression, we also investigated whether Nrf2 mediates the CD36 gene upregulation observed in the LST group. A chromatin immunoprecipitation (ChIP) assay revealed that in the RG prevents Nrf2-dependent CD36 up-regulation.

\section{Methods \\ Animals}

Two-month old female inbred strain C57BL/6J and $\mathrm{C} 3 \mathrm{HeJ} / 6 \mathrm{~J}$ mice that differ strikingly in aortic fatty streak development when fed a high-fat diet were housed at $25^{\circ} \mathrm{C}$ on a 12 -hour light/dark cycle and provided with food and water ad libitum. At day 0, C57BL/6J animals were maintained either on a chow diet or a high-cholesterol diet containing $15 \%$ fat, $1.25 \%$ cholesterol, and $0.5 \%$ cholic acid (Panlab, S.L., Barcelona, Spain) for 12 weeks. Twenty-three mice per group were randomly selected in one of the following groups: group 1 (control) was maintained on chow diet; group 2 (control) was maintained on high-cholesterol diet; group 3 constituted C57BL/6J mice maintained on high-cholesterol diet that received $\mathrm{RG}$ administered at $25 \mathrm{mg} / \mathrm{Kg} /$ day; and group 4 was composed of C57BL/6J mice on high-cholesterol diet that received LST administered in the drinking water at $100 \mathrm{mg} / \mathrm{L}$. RG was administered by food and was monitored every day. Similarly, the water consumption in the LST group was monitored weekly. Each mouse was estimated to drink $1.5 \mathrm{ml}$ of water/10 grams of body weight/ day. A group of $25 \mathrm{C} 3 \mathrm{HeJ}$ female mice fed on high-cholesterol diet was also created (group 0 ). 
All experimental procedures were performed in accordance with the animal welfare guidelines of the Hospital Universitario de Gran Canaria Dr. Negrín; the national guide (Royal Decree 223/1988) and the international guide (Guide for the Care and Use of Laboratory Animals, published by the US National Institutes of Health) for the use and care of animals for experimentation. All investigators directly involved in the handling of animals possess the relevant approvals from the Ministry of Agriculture, Fisheries and Food of the Directorate General of Animal Husbandry of the Canary Islands Government in the B and C categories (Royal Decree 1201/2005).

Animals were anesthetized with $5 \mu$ l per grams of body weight using an anesthetic cocktail of Ketolar (ketamine hydrochloride at $50 \mathrm{mg} / \mathrm{ml}$ ) (Parke-Davis, S.L.; Barcelona, Spain) and Rompún (xylazine at 2\% administered at 2.5 $\mathrm{mg} / \mathrm{ml}$; Bayer Health Care, AG, Germany) in saline solution. Blood samples were collected by cardiac left ventricular punction in three animals per group, chosen between housed at days 1, 25,50,75, and 100. At the end of the study period (day 105) five mice per group were anesthetized and transcardially perfused with saline following tissue samples collection. Liver samples were obtained, snap-frozen by immersion in liquid nitrogen and stored at $-20^{\circ} \mathrm{C}$ until use.

\section{Analysis of plasma lipids and lipid peroxidation}

Blood was collected from 6-hour fasted animals and plasma samples were stored at $-70^{\circ} \mathrm{C}$. Insulin was measured by the Abbott kit insulin (Abbott Laboratories, USA). Plasma levels of total cholesterol (TC), triglyceride (TG) and HDL-cholesterol were measured enzymatically by using Wako kits. Total plasma lipid hydroperoxide (LOOH) content was calculated by the Xylenol Orange (FOX) assay as described elsewhere [33] and analyzed after being mixed with copper sulphate at a final concentration of $10 \mu \mathrm{M}$ at $37^{\circ} \mathrm{C}$ for $24 \mathrm{~h}$, using triphenyl phosphine (TPP) for signal authentication. The absorbance of the supernatants was monitored at $560 \mathrm{~nm}$ and the hydroperoxide content determined using a molar absorption coefficient of $4.3 \times 10^{4} \mathrm{M}^{-1} . \mathrm{cm}^{-1}$ or by reference to an $\mathrm{H}_{2} \mathrm{O}_{2}$ standard curve.

LOOH content was also measured in the supernatant of cultured cells by the modified method of Auerbach [34]. To $40 \mu \mathrm{l}$ aliquots were added to a 96-well microtiter plate containing ethanol $(10 \mu \mathrm{L})$ and $N$-benzoyl leucomethylene blue (LMB) color reagent $(100 \mu \mathrm{L})$. The LMB reagent was prepared with $5 \mathrm{mg}$ of LMB (Tokyo Kasei Kogyo) dissolved in $8 \mathrm{~mL}$ of $\mathrm{N}, \mathrm{N}$-dimethyl-formamide and $90 \mathrm{~mL}$ of

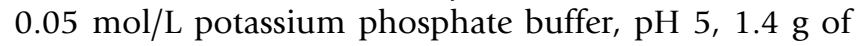
Triton X-100, and $5.5 \mathrm{mg}$ of hemoglobin. Linoleic acid hydroperoxide (13-hydroperoxy-9,11-octadecadienoic acid, ranging from 1 to $20 \mathrm{nmol}$ in $10 \mu \mathrm{L}$ ethanol) was added as a standard to wells containing saline $(40 \mu \mathrm{L})$ and $\mathrm{LMB}$. After 40 minutes at room temperature, the standards and samples were read at $650 \mathrm{~nm}$ using a microtiter plate reader. A standard curve for absorbency versus LOOH concentration was generated, and the hydroperoxide levels in samples were determined from this curve.

\section{Analysis of Paraoxonase/arylesterase activities}

Paraoxonase (PON p. ase) and arylesterase (PON ar.ase) activities were evaluated by previously described methods $[35,36]$.

\section{Analysis of Total Nitric Oxide Metabolites}

Plasma samples were filtered through Microcon YM-10 columns (Millipore). Total nitric oxide metabolites concentration was evaluated in sample columns effluent by using a colorimetric kit assay according to the manufacturer instructions (R \& D Systems).

\section{Cell-Free Dichlorofluorescein (DCF) assay}

Total HDL was prepared by precipitation using the DS1 reagent. DS1 was prepared dissolving in water $10 \mathrm{mg} / \mathrm{L}$ dextran sulphate (Dextralip ${ }^{\circledR} 50$, Sigma), $0.5 \mathrm{~mol} / \mathrm{L} \mathrm{MgCl}_{2}$, and $0.05 \%$ sodium azide. The protein content of precipitated HDL was determined and HDL samples were subsequently adjusted to similar protein content with saline.

The cell-free Dichlorofluorescein (DCF) assay was performed essentially as described [37]. Ten microliters of DCFH-DA (Molecular Probes, Eugene, OR) dissolved methanol were placed in polypropylene tubes and evaporated under vacuum. A similar procedure was conducted following addition of L- $\alpha$-1-palmitoyl-2-arachidonoyl-snglycero-3-phosphocholine (PAPC) $(10 \mu \mathrm{l}$ at $2.5 \mathrm{mg} / \mathrm{ml}$ in chloroform) and $20 \mu \mathrm{l}$ of HPODE at $0.5 \mathrm{mg} / \mathrm{ml}$ in ethanol. Finally, $25 \mu \mathrm{l}$ of saline or HDL at $500 \mu \mathrm{g} / \mathrm{ml}$ was added to each tube and the volume adjusted to $1 \mathrm{ml}$ with saline. Samples were incubated for 2 hours at room temperature in the dark before counting in a FLx800 Microplate Fluorescence Reader. Authentic L- $\alpha$-1-palmitoyl-2arachidonoyl-sn-glycero-3-phosphocholine (PAPC) was obtained from Avanti Polar Lipids (Alabaster, AL) and 13(S)-HPODE was obtained from Biomol (Plymouth Meeting, PA).

\section{Cell Culture and Stimulation}

3T3-L1 pre-adipocytes were grown in Dulbecco's modified Eagle medium (DMEM) to confluence and differentiated with $0.5 \mathrm{mM}$ of isobuthylmethylxanthine (IBMX), 1 $\mu \mathrm{M}$ dexamethasone, $10 \mu \mathrm{g} / \mathrm{ml}$ insulin and $5 \%$ calf serum for 48 hours essentially as described [26]. Insulin was maintained for 2 additional days in the differentiated control cells group. For the remaining groups, cells were washed with PBS and incubated in medium containing RG at $40 \mu \mathrm{M}$, LST at $100 \mu \mathrm{M}$, or a vehicle for 5 days. 
Medium was replaced every day. At day 5, quiescent cells incubated with RG and LST were exposed to oxidized PAPC (ox-PAPC) for $24 \mathrm{~h}$. Oxidized PAPC (ox-PAPC) was prepared and isolated as described [38]. 3T3-L1 preadipocyte and adipocytes were stained with Oil Red O essentially as described [39].

\section{Analysis of mRNA levels by real-time PCR}

Total RNA was isolated from mice liver and cells by the Chomczynski method. Hepatic and cultured cells cDNAs was synthesized using MMLV (Roche Diagnostics) following the instructions provided by the manufacturer. Realtime PCR was performed on a LightCycler device using the FastStart DNA Master SYBR Green I (Roche Diagnostics) according to the provided protocol. Amplifications of PPAR $\gamma$ gene and of the PPAR $\gamma$ target gene SCARB1 were performed using the primers pairs: 5'-TTTTCAAGGGTGCCAGTTTC-3' and 5'-AATCCTTGGCCCTCTGAGAT-3' spanning 198 base pairs of the exon 6 of the PPAR $\gamma$ gene [GenBank accession number NM_011146] and 5'GAAAAAGCGCCAAGTACAGC-3' and 5'-CAGGCTGTGGGAACTCTAGC-3' spanning 248 bp of the SCARB1 gene [GenBank NM 016741]. Fragments of the CD36; Paraoxonase 1 (PON1); 5-lipoxygenase (Alox5); 15 lipoxygenase type A (Alox15) and 15 lipoxygenase B (Alox15b) genes were amplified using the following primer pairs: 5 'GAGCAACTGGTGGATGGTTT-3' and 5'-GCAGAATCAAGGGAGAGCAC-3' which yields a 207 bp fragment of the CD36 gene [GenBank NM_007643]; 5'-CACCCGTCTCGATTCCTTTA-3' and 5'-CAGCCTGTCCATCTGTCTCA-3' that amplified a 178 bp fragment of the PON1 gene [GenBank NM 011134]; 5'-GTGCTGCTTGAGGATGTGAA-3' and 5'-CTACGATGTCACCGTGGATG-3' that amplified a 235 bp fragment of the Alox5 gene [GenBank L42198]; 5'-GATTGTGCCATCCTTCCAGT-3' and 5'-CAGGGATCGGAGTACACGTT-3' that amplified a 186 bp fragment of the Alox15 [GenBank NM 009660]; 5'GCTAAAGCATGCCAGTGTGA-3' and 5'-GCTCTGATTAACGGCTTTGC-3' that yield a 229 bp fragment of the Alox15b gene [GenBank NM 009661]. Fragments of the IL-6, CYBA (p22phox), eNOS and iNOS genes were amplified using previously described primers [40,41]. When linearity and efficiencies were similar between targets and the reference amplified glyceraldehyde-3-phosphate dehydrogenase (GAPDH) fragment, relative expression analyses were performed by the comparative threshold cycle quantitation method. Alternatively, targets and the GAPDH fragment were analyzed by using serial dilutions of pooled cDNA and then applying the standard curve quantitation method. The 223 bp fragment of the GAPDH gene was amplified with the following primers: 5'-ACA CAT TGG GGG TAG GAA CA-3' and 5'-AAC TTT GGC ATT GTG GAA GG-3' [GenBank NM_008084]. Primers design was done by using the public domain software Primer3 [42].

\section{Chromatin immunoprecipitation assays}

Liver samples $(\approx 0.05$ grams per mouse) were allowed to thaw on ice in serum-free DMEM and then cross-linked with $5 \%$ formaldehyde for 5 minutes. Liver fragments were homogenized and nuclear and cytosolic fractions extracts prepared by using a nuclear extraction kit from Active Motif according to the manufacturer instructions. Nuclear lysates were sonicated on ice. As a positive control (input) undiluted aliquots were retained for further processing in parallel with all the other samples at the reversal of the crosslinked step. ChIP assays were performed adding to the chromatin complexes $10 \mu \mathrm{l}$ of $\alpha$ Nrf2-C20 or PPAR $\gamma$ (H-100) antibodies (Santa Cruz) or without antibody overnight at $4^{\circ} \mathrm{C}$. DNA samples were recovered and subjected to analysis by real time PCR amplification. Primers used were specifically designed to amplify a putative antioxidant response element (ARE) in the CD36 gene promoter and a putative peroxisome proliferator response element (PPRE) in the Apolipoprotein A-I (Apo A-I) gene promoter by using the software Primer3. Primers flanking a PPRE at iNOS gene were as described [43]. A putative CD36 ARE (RTGAYnnnGC) site was identified located between base positions 1425 to 1434 in the CD36 gene promoter [GenBank AF434766] and primers flanking this sequence were designed with the sequences: 5'-TGCTCTGAGCTCTACCCTCTG-3' and 5'-TCTGTCCCCTCTTTTGCAGT-3'. The CD36 promoter sequence was analyzed and completed for gap and errors considering the previously published information $[44,45]$. Mouse sequence data homologous to the Apo AI 5' UTR region of the Rattus norvegicus Apo A-I promoter sequence [GenBank X54210] was identified after a BLAST search. A large fragment encompassing 562 bases from 171971 to 172532 of the Mus musculus chromosome 9 sequence, clone RP24-302M3 [GenBank AC116503], matched with the promoter sequence and was subsequently explored to find potential PPRE binding sites. A consensus sequence of the form RG(G/T)TCA was found. The identified sequence AGTTCAAGGATCA constitutes a DR1 element of the form with a perfect RG(G/T)TCA 5'motif and an imperfect 3'-motif. Primers flanking a putative PPRE in the apo A-I promoter regions used were $5^{\prime}-$ TCTGGGTGTCCAGCTCTTCT-3' and 5'-CCTGTTTGCCCACTCTGTTT-3'. Similarly, a BLAST search was performed using the SCARB1 promoter region of Rattus norvegicus [gi:50881992]. A fragment that was in common with the BAC clone of the Mus musculus chromosome 5 [gi:71533446] was selected. A PPRE site was identified in the fragment encompassing 360 base pair. This sequence was used to design primers flanking the SCARB1 promoter region with the sequences 5'-TTGTGTCCTGAGTGGAATGC-3' and 5'-AGCAGGGTGGTAGGGACTCT-3'. The CD36, SCARB1 and apo A-I promoter regions were also amplified by standard PCR and subjected to gel electrophoresis. Agarose bands were excised, purified (QIA- 
GEN Gel Extraction Kit) and sequenced on an ABI Prism 310 device using the BigDye ${ }^{\circledast}$ v. 3.1 Terminator Cycle Sequencing Kit according to the manufacturer instructions (Applied Biosystems).

\section{Statistical analyses}

Quantitative variables are presented as mean \pm SEM unless otherwise specified and qualitative variables as percentages. Pair wise related group comparisons were performed using the Wilcoxon test whereas the MannWhitney U-test was used for comparisons of unrelated groups. The level of significance was set at $P<0.05$.

\section{Results \\ Lipid profile and HDL concentration between treated groups}

No differences in the food and water consumption were visible among animals of one experimental group or between experimental or control groups. There were no significant differences in insulin levels between treated and untreated mice.

Animals that were fed on HFHC treated with RG showed a significant difference in HDL-cholesterol level with respect to mice fed only on HFHC diet at the beginning ( $\mathrm{p}$ $=0.02)$ and at the end of the study period $(\mathrm{p}=0.019)$. Mice treated with RG showed a significant increase in HDL-cholesterol levels between day 1 and day 100 ( $\mathrm{p}=$ 0.016 ) (Figure 1b). No differences in total cholesterol and triglycerides levels were observed.

As shown in Figure 1d, we found lower, albeit not significant $(p=0.06)$, levels of total LOOH in mice fed on HFHC diet treated with RG with respect to those observed in mice fed on HFHC diet. Also, lower levels of $\mathrm{LOOH}$ were observed in the RG group with respect to mice treated with LST or even with respect to the C3HeJ control group. A significant difference in $\mathrm{LOOH}$ content in the RG group between days 1 and $100(\mathrm{p}=0.02)$ was observed.

As pointed out above, raised HDL levels in RG with respect to LST treated mice were observed. Increase in apoA-I gene, a main determinant of HDL concentration levels, might occur after RG treatment because of its ability to act on PPRE elements located at the apoA-I gene which might also preserve HDL-associated antioxidant properties [18]. Therefore, these two possibilities were analyzed as follows. First, we tested the ability of isolated HDL to inhibit the oxidation of PACP by HPODE by the DCF cell-free assay. Fluorescence signal comparisons between HDL obtained from either C57BL/6J mice on a chow diet and C57BL/6J that fed a HFHC between day 1 and day 100 were significant (Figure 2a). Therefore, both time elapsed and hypercholesterolemic diet were associated with a reduction of the HDL antioxidant properties.
As deduced from Figure $2 \mathrm{a}$, we observed that both RG and LST treatment preserved the antioxidant properties of HDL. Interestingly, no differences in the HDL-linked Paraoxonase and arylesterase activities as well as in the PON1 gene expression were observed between pharmacological treated groups (not shown). Second, the Apo A-I proximal promoter levels were evaluated after PPAR $\gamma$ ChIP assay as described in our methods. As depicted in Figure 2b, experiments demonstrated respectively a $63.5 \%$ and a $92.5 \%$ of DNA amplified after ChIP in the LST and RG treated mice groups with respect to mice fed on HFHC diet. The difference between both pharmacological treated animal groups was not significant. This finding suggested that the PPAR $\gamma$-mediated transcription of apo-A-I was not different in treated groups and interestingly that a preserved PPAR $\gamma$ activity was also present in the LST group.

\section{PPAR $\gamma$ and the levels of the PPAR $\gamma$-responsive gene SCARB I were similar between treated groups}

As seen in Figure $3 a$ at day 100, a significant increase in PPAR $\gamma$ gene relative expression was observed in animals fed on HFHC diet with respect to chow $(\mathrm{p}=0.01)$. No difference was observed in the PPAR $\gamma$ expression levels between LST and RG treated mice. Gene expression levels of the PPAR $\gamma$ response gene SCARB1 were next evaluated. At day 100 a significant decrease in SCARB1 gene expression in mice fed on HFHC diet with respect to mice fed on chow diet $(\mathrm{p}=0.02)$ was observed. SCARB1 expression levels were significantly higher in hypercholesterolemic mice treated with LST in respect to untreated HFHC fed mice. Jointly considered PPAR $\gamma$ and SCARB1 expression data are suggestive of a preserved PPAR $\gamma$ activity in both pharmacological treated groups. To specifically evaluate this PPAR $\gamma$ preserved activity, ChIP assays were conducted. Following PPAR $\gamma$-mediated immunoprecipitation assays revealed that there was a $38 \%$ reduction in the amplified level of SCARB1 promoter region that was accessible to PPAR $\gamma$ in mice fed with a HFHC diet compared to mice fed a control low-fat diet $(\mathrm{p}=0.109)$ (Figure $3 c$ ). It seems that in mice fed on HFHC diet, in spite of a significant increase in the PPAR $\gamma$ expression levels, this nuclear receptor seems to be unable to efficiently bind to the PPRE site in the SCARB1 gene. In this context, we observed that in those animals fed on HFHC diet that were also treated with LST or RG, the amplified values of SCARB1 DNA were respectively $162 \%$ and $265 \%$ higher than those in $\mathrm{C} 57 \mathrm{BL} / 6 \mathrm{~J}$ fed a HFHC diet. The difference between LST and RG groups did not reach statistical significance. 
a

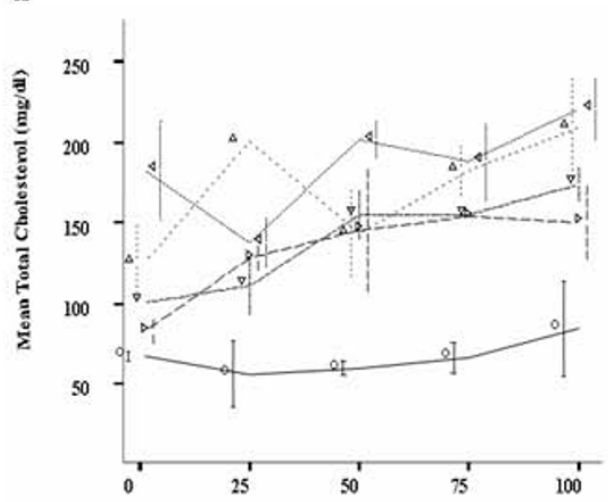

c

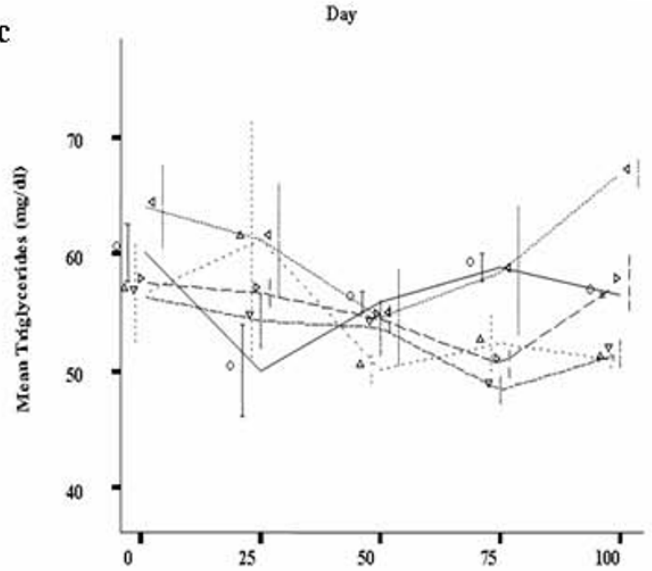

Day b $\quad$ GROUPS

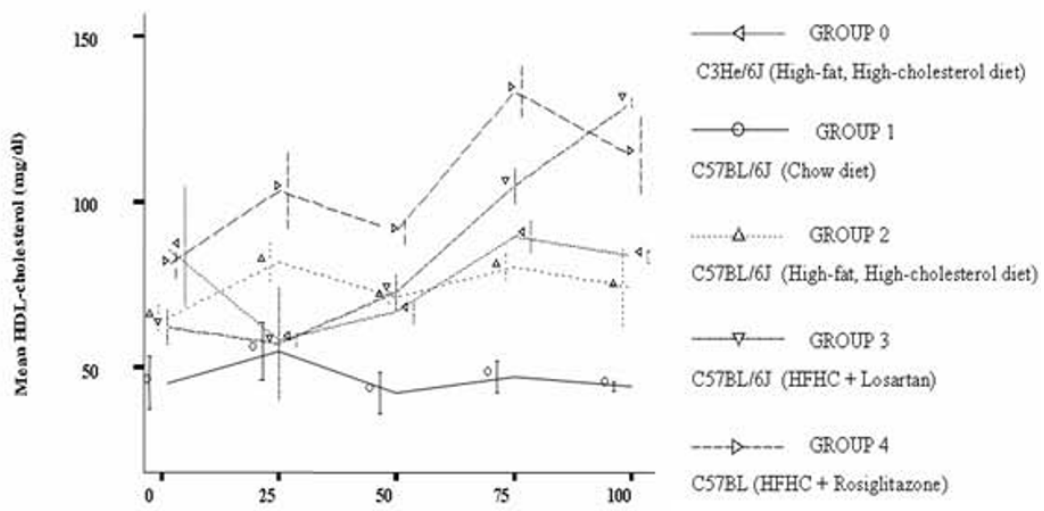

d

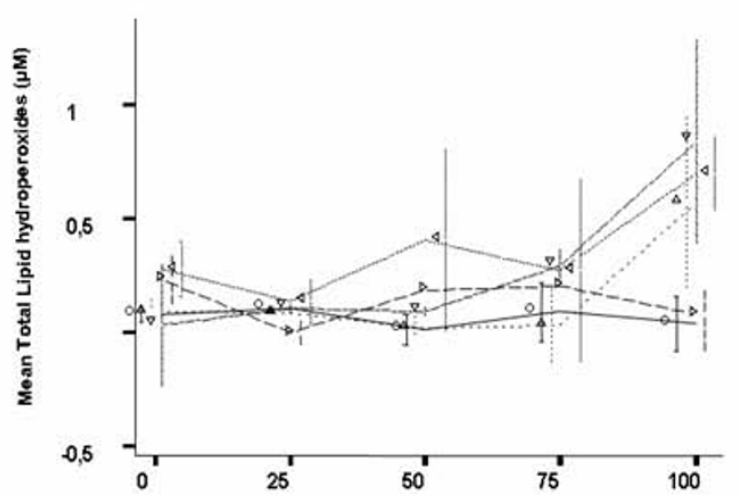

Day

Figure I

Mean total cholesterol (a), HDL-cholesterol (b), triglycerides (c) and lipid hydroperoxides (d) content in plasma of study groups. Triplicate measurements were taken in three animals per group before the onset of the study period (day 0), at day I and each 25 days elapsed after completing 100 days. Inter-group comparisons were made at day I and at day 100 and intra-group between days I and 100. Data are expressed as mean \pm SD.

\section{Difference in CD36 relative gene expression between treated mice; rosiglitazone prevents Nrf2-dependent CD36 up-regulation}

Increased gene expression level of CD36 gene was shown in animals that were fed on HFHC diet with respect to chow-fed mice $(p=0.02)$ (Figure $4 a)$. We observed a significant increase in CD36 relative expression level in mice treated with LST with respect to mice control groups feeding on either chow or HFHC diet ( $p<0.05$ for both). Mice that were fed on HFHC diet treated with RG showed higher but not significant CD36 relative gene expression level regarding chow-fed mice. A significant reduction in CD36 expression levels was observed in RG treated mice with regard to both HFHC control mice and HFHC mice treated with LST ( $\mathrm{p}<0.05$ for both).
Previous results suggested similar levels of PPAR $\gamma$ activity between our treated groups. Studies have established the role of Nrf2 as a novel signalling pathway involved in the regulation of the CD36 gene. Evidence that ox-LDLs and certain oxidized lipids of LDL particles are inducers of Nrf2 [21] has been reported. Thus, we next explored the possibility that Nrf2 could be playing a pivotal role in the observed diminished total plasma LOOH levels in mice that fed a HFHC diet treated with RG with respect to either LST treated and untreated hypercholesterolemic mice as well as in the observed diminution in the relative expression levels of CD36 gene in the RG mice group with respect to the mice LST group. To address this possibility, ChIP assays using an antibody against Nrf2 followed with real-time analysis of the ARE site at the CD36 gene promoter identified as described in the methods were per- 

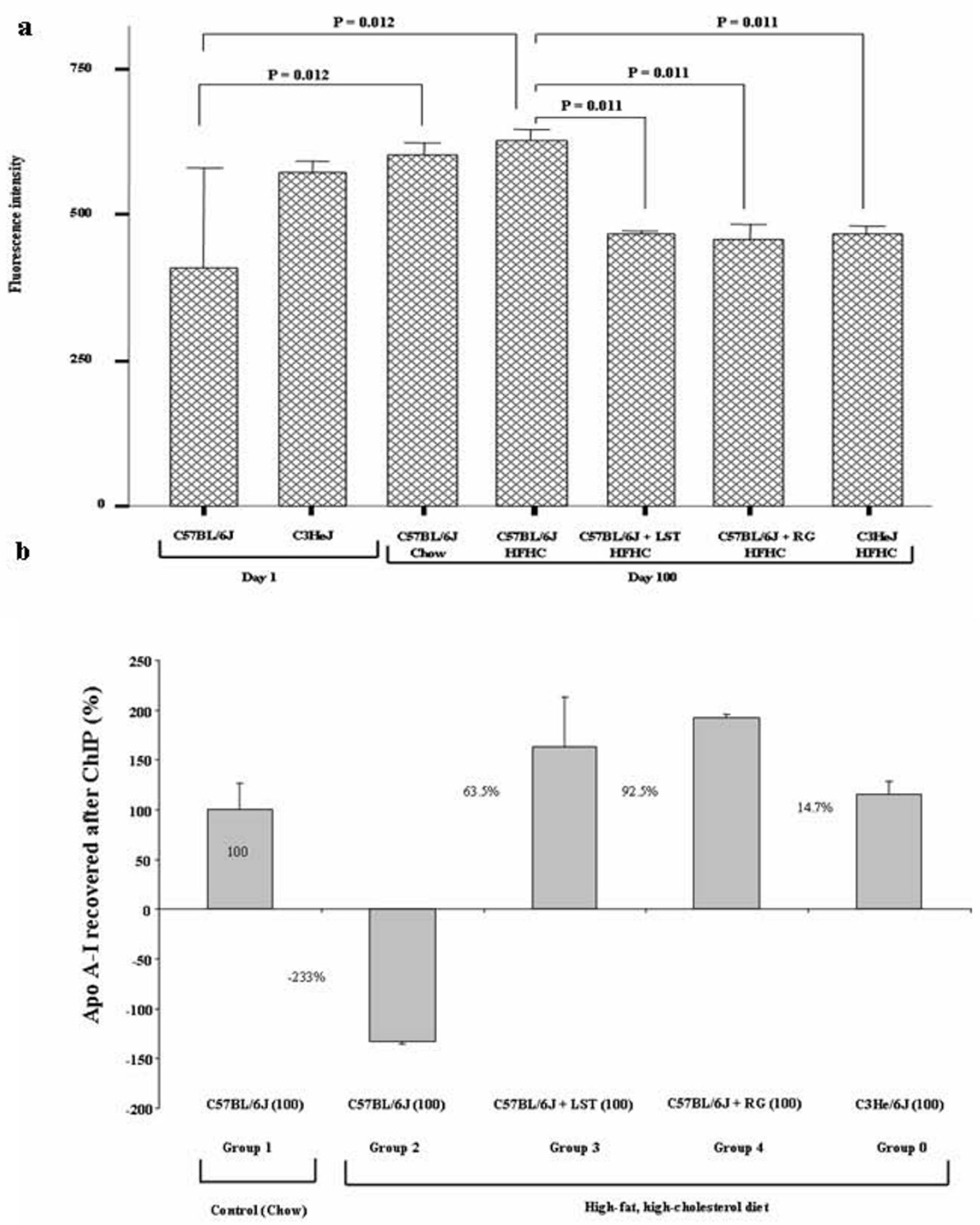

Figure 2

Treatments preserve HDL antioxidant properties and apolipoprotein A-I-(apo A-I)-PPAR $\gamma$-mediated gene expression. (a). Fluorescence intensity (arbitrary units) was determined as described in Methods. There was no difference in the fluorescence signal levels measured of the HDL isolated from mice under control diet with respect to that obtained from mice that fed a HFHC diet after I day elapsed; thus the average fluorescence value obtained of the HDL from both groups was taken as "Day I" reference value. Data are mean \pm SD from thee separate experiments. (b). ChIP with a PPAR $\gamma$ antibody of study groups were used to amplify an apo A-I promoter fragment. ChIP figures percentages indicate increments or decrements regarding C57BL/6] mice fed HFHC diet. Data of C57BL/6] mice fed chow diet was established as 100\%.

formed. A significant Nrf2-dependent increase in the amplified CD36 gene promoter region was observed in animals fed with a HFHC diet with respect to control chow mice $(\mathrm{p}<0.05)$ (Figure $4 \mathrm{~b})$; similarly, mice treated with LST showed increased amplification levels of the CD36 promoter region regarding chow mice ( $p<0.05$ for 
a

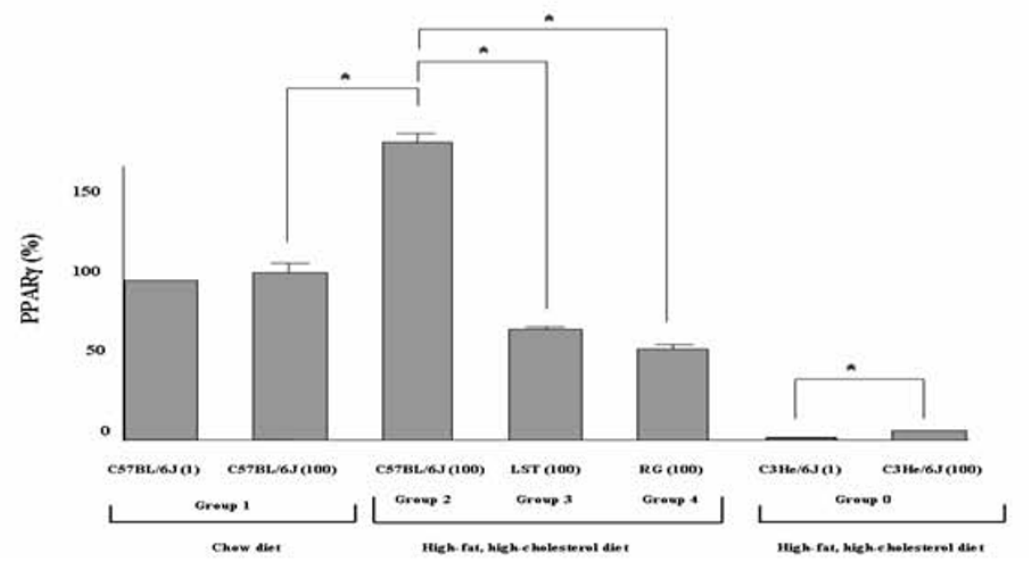

b
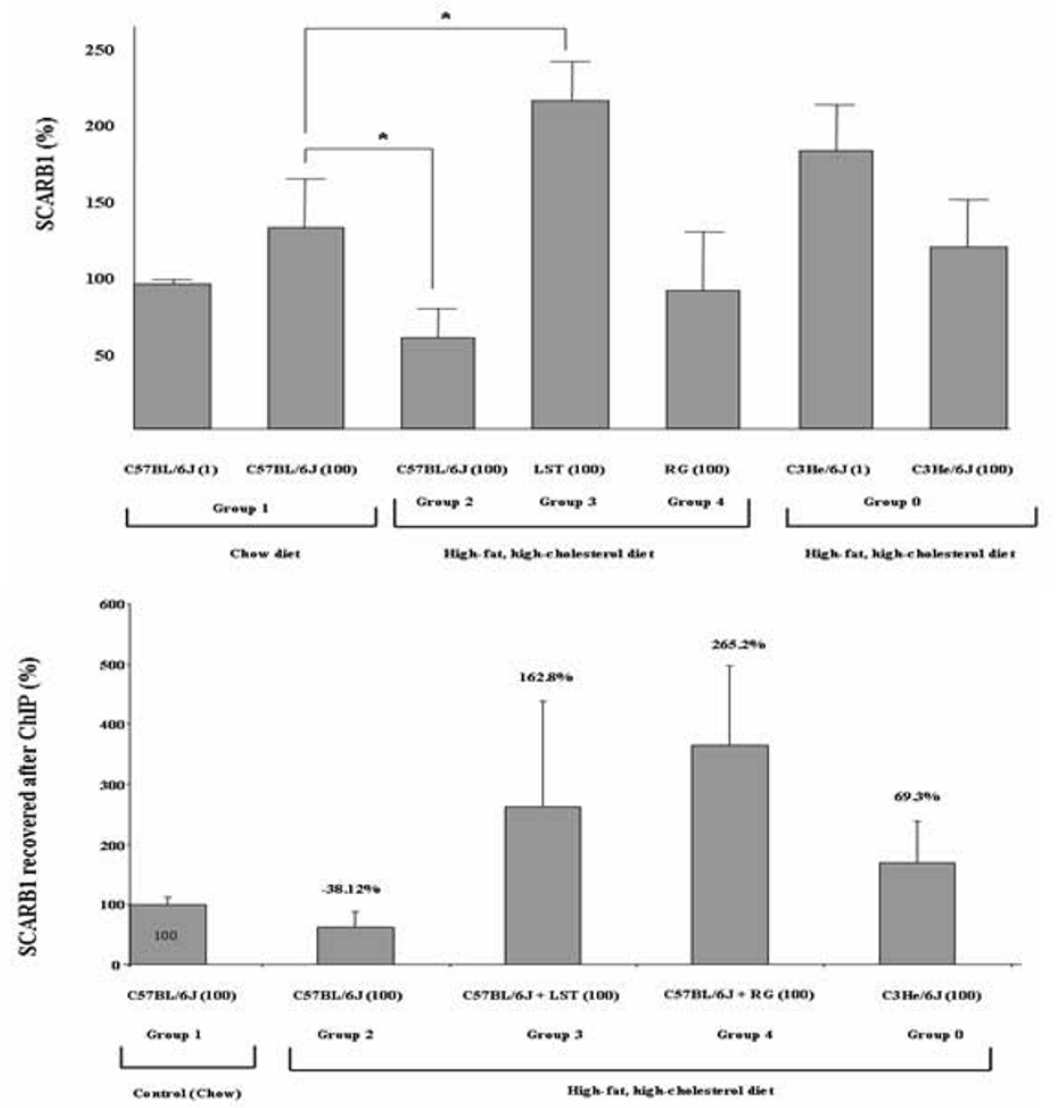

Figure 3

Treatments preserve PPAR $\gamma$ activity and PPAR $\gamma$ responsive gene expression. (a) PPAR $\gamma$ mRA relative expression in pooled liver samples from analyzed groups normalized to GAPDH expression. Results are expressed as mean \pm SEM percentage of mean values obtained from equal numbers of $\mathrm{C} 57 \mathrm{BL} / 6 \mathrm{~J}$ and $\mathrm{C} 3 \mathrm{He} / 6 \mathrm{~J}$ mice. $* \mathrm{P}<0.05$. (b). SCARBI mRNA relative expression in liver samples from analyzed groups normalized to GAPDH expression. *P < 0.05 (c). ChIP with a PPAR $\gamma$ antibody of study groups was used to amplify a SCARBI promoter fragment. ChIP figures percentages indicate increments or decrements regarding C57BL/6] mice fed HFHC diet. Data of C57BL/6] mice fed chow diet was established as $100 \%$.

both). Those RG treated mice showed moderate but significant lower amplification levels of the CD36 promoter fragment with respect to the amplification levels obtained in the control chow-fed group (Figure 4b). Remarkably, as depicted in Figure $4 \mathrm{~b}$, we found a $125.8 \%$ decrease in 


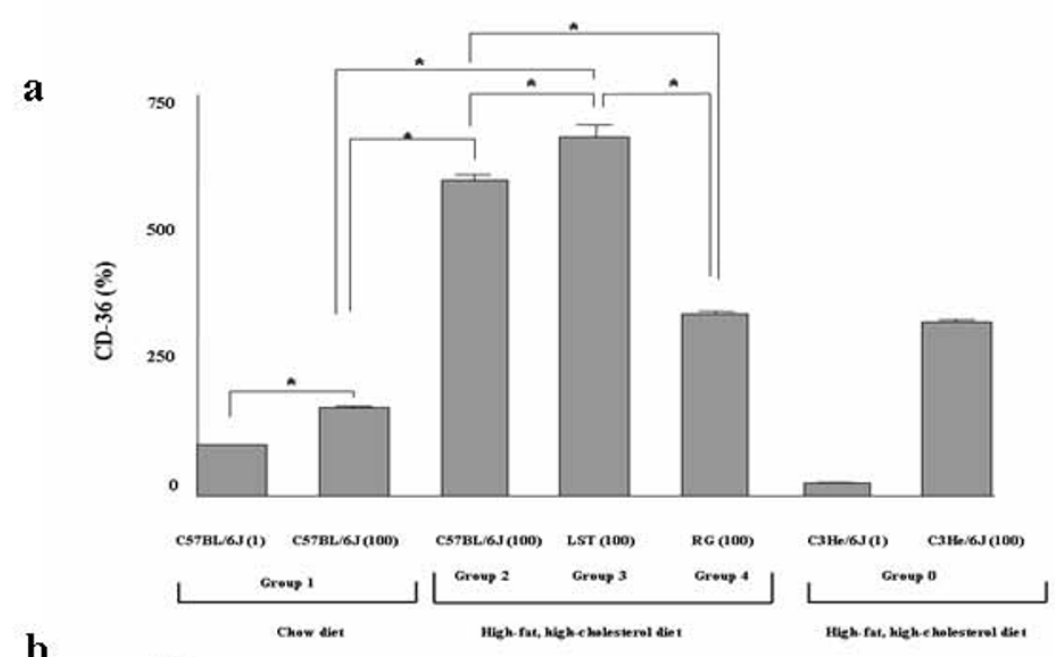

b

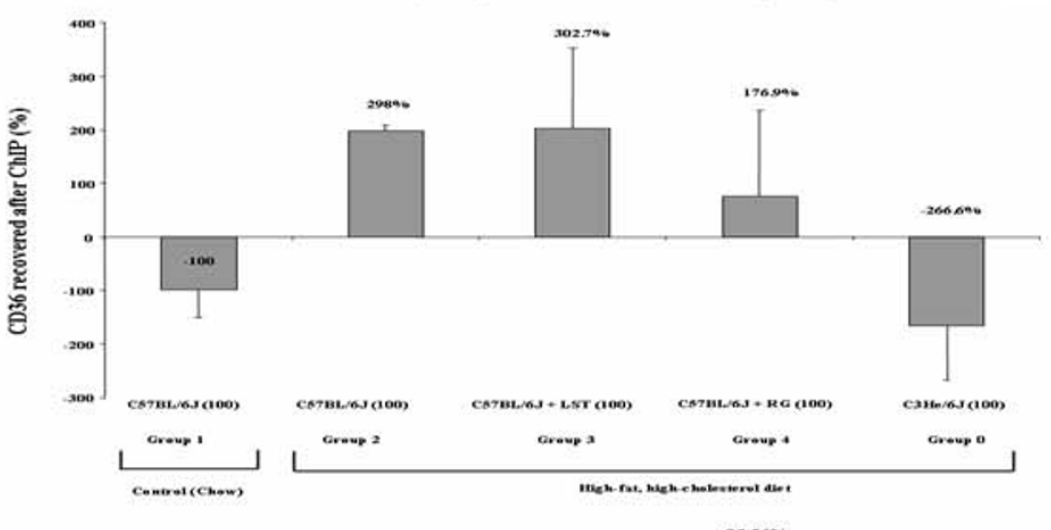

$\mathbf{c}$

\section{Figure 4}

Rosiglitazone prevents Nrf2-depedent CD-36 up-regulation in hypercholesterolemic C57BL/6J mice. (a) CD36 mRNA relative expression in pooled liver samples from analyzed groups normalized to GAPDH expression. *P < 0.05 . (b) ChIP with an Nrf2 antibody of study groups was used to amplify a CD36 promoter fragment. ChIP figures percentages indicate increments or decrements regarding C57BL/6J mice fed HFHC diet. Data of C57BL/6] mice fed chow diet was established as 100\%. (c) Quiascent day-5 adipocytes incubated with RG and LST were treated with ox-PACP for additional 24 h. RNA was isolated to measure adipose protein 2 by conventional PCR and CD36 expression using real-time PCR. Values were normalized to GAPDH expression. Figure bar plots represent mean \pm SEM percentage from vehicle-treated cells of at least 4 experiments with duplicate measurements. 
hypercholestelomic mice treated with RG with respect to LST treated mice $(\mathrm{p}=0.02)$.

\section{Rosiglitazone prevents CD36 up-regulation in $3 T 3$ differentiate cells exposed to ox-PACP}

Adipocyte differentiated cells were treated with LST or RG at the doses and times previously described. Differentiation was confirmed by the increased oil-red staining and evaluating the relative expression of the adipogenic marker gene adipose protein 2 (ap2). Statistical comparisons revealed that cells treated with the differentiation cocktail showed significant higher level of ap2 amplified fragment regarding all analyzed groups. Those LST or RG treated cells showed similar levels of ap2 gene. Cells treated with both RG and LST showed diminished CD36 expression levels than those observed in differentiated untreated cells ( $\mathrm{p}<0.05$ for both) (Figure 4c). However, no difference between both treated cell groups was observed. Then, we tried to simulate in vivo oxidative conditions by exposing treated cells to ox-PAPC. Cells treated with LST exposed to ox-PAPC showed no difference in the CD36 relative expression levels with respect to its differentiated cells group $(p=0.07)$ (Figure $4 c)$. However, a statistical significant reduction in CD36 relative expression levels in cells treated with RG exposed to ox-PAPC with respect to differentiated control non-exposed cells ( $\mathrm{p}=$ 0.03 ) was observed (Figure 4c).

Moreover, we found that the LOOH content in the supernatant of differentiated cells was significantly increased with respect to its undifferentiated controls $(\mathrm{p}=0.007)$. This increase positively correlated with the CD36 gene expression levels $(\mathrm{p}=0.034)$. On the contrary, we observed that both LST and RG treatments produced a significant decrease in the $\mathrm{LOOH}$ content with respect to differentiated cells group $(\mathrm{p}=0.044$ and $\mathrm{p}=0.001$, respectively). Again, no difference in LOOH levels was observed between treated cells. Cells treated with RG or LST exposed to ox-PACP showed mean lower levels of LOOH than those obtained in unexposed cells treated only with LST or RG ( $\mathrm{p}<0.001$ for both). Statistical comparison showed no differences between either ox-PACP treated group. Notably, this occurred in spite of the fact that CD36 gene expression levels were observed to be higher in cells treated with LST plus ox-PACP regarding cells treated with RG plus ox-PACP.

\section{Assessing the relative expression of Nitric Oxide Synthase and Interleukin-6 genes}

RG treated mice showed a statistically significant reduction of the iNOS relative gene expression, with respect to both chow-fed animals and HHFC-fed mice treated with LST ( $\mathrm{p}<0.05$ for both) (Figure 5a). IL-6 relative gene expression values although lowers in RG treated mice did not differ among analyzed groups (not shown).
Mean eNOS gene expression values in mice fed on a HFHC diet treated with RG or LST were smaller than those obtained in HFHC fed control mice. This reduction was significant for the comparison of mice treated with $\mathrm{RG}$ with respect to HFHC-fed control group $(p=0.04)$ (Figure $5 b)$. Accordingly, group comparison showed that plasma nitric oxide metabolites values were found to be reduced in $R G$ regarding LST treated mice $(\mathrm{p}=0.02)$.

\section{Differences in the iNOS gene expression and its PPAR $\gamma$ dependence}

ChIP assays using an antibody against PPAR $\gamma$ followed by real-time amplification of an iNOS gene fragment flanking the recently identified PPRE [43] at iNOS gene showed a $119 \%$ increase in average mean amplification values in mice under HFHC diet with respect to those obtained in chow-fed mice $(-100 \%)(\mathrm{p}=0.1)$ (Figure $5 \mathrm{c})$. In line with our previous results, amplification levels were higher after amplifying DNA from PPAR immunoprecipitates obtained from HFHC-fed mice treated with LST and RG (199\% and $168 \%$ respectively). Comparison between treated groups yielded no difference $(\mathrm{p}>0.05)$ (Figure 5c). Thus, although PPAR $\gamma$ expression levels were not increased in these groups regarding mice fed only on a HFHC diet, the ability to access PPRE binding sites in target genes seems to be preserved in both treated mice groups. Thus, the observed iNOS up-regulation in LST treated mice seems to be independent of the PPAR preserved activity.

\section{Discussion}

In this study we demonstrated that the administration of RG or LST to diet-induced atherosclerosis susceptible mice fed a HFHC diet preserves to the same extent in both groups the activity of nuclear receptor PPAR $\gamma$ Conclusions derived from the analysis of the expression levels of PPAR $\gamma$ responsive gene SCARB1 and the amplification levels of PPRE binding sites of target genes amplified after ChIP which were shown to be approximately equal.

Previous studies in two murine models of atherosclerosis have shown that treatment with PPAR $\gamma$ agonists protected against the development of atherosclerosis [17-19]. However, lessons obtained from murine models of atherogenesis with or without diabetes should be viewed with caution given the known differences between vascular lesions from those animal models compared to those seen in humans [46]. Interestingly, we find that in spite of the similarly preserved PPAR $\gamma$ activity, RG administration was associated with a better "antiatherogenic" profile than this found in animals treated with LST exposed to the same diet. Thus, we found that hypercholesterolemic mice treated with RG showed inferior levels of total peroxidized lipids than those measured in hypercholesterolemic mice treated with LST. Moreover, when the relative gene expres- 

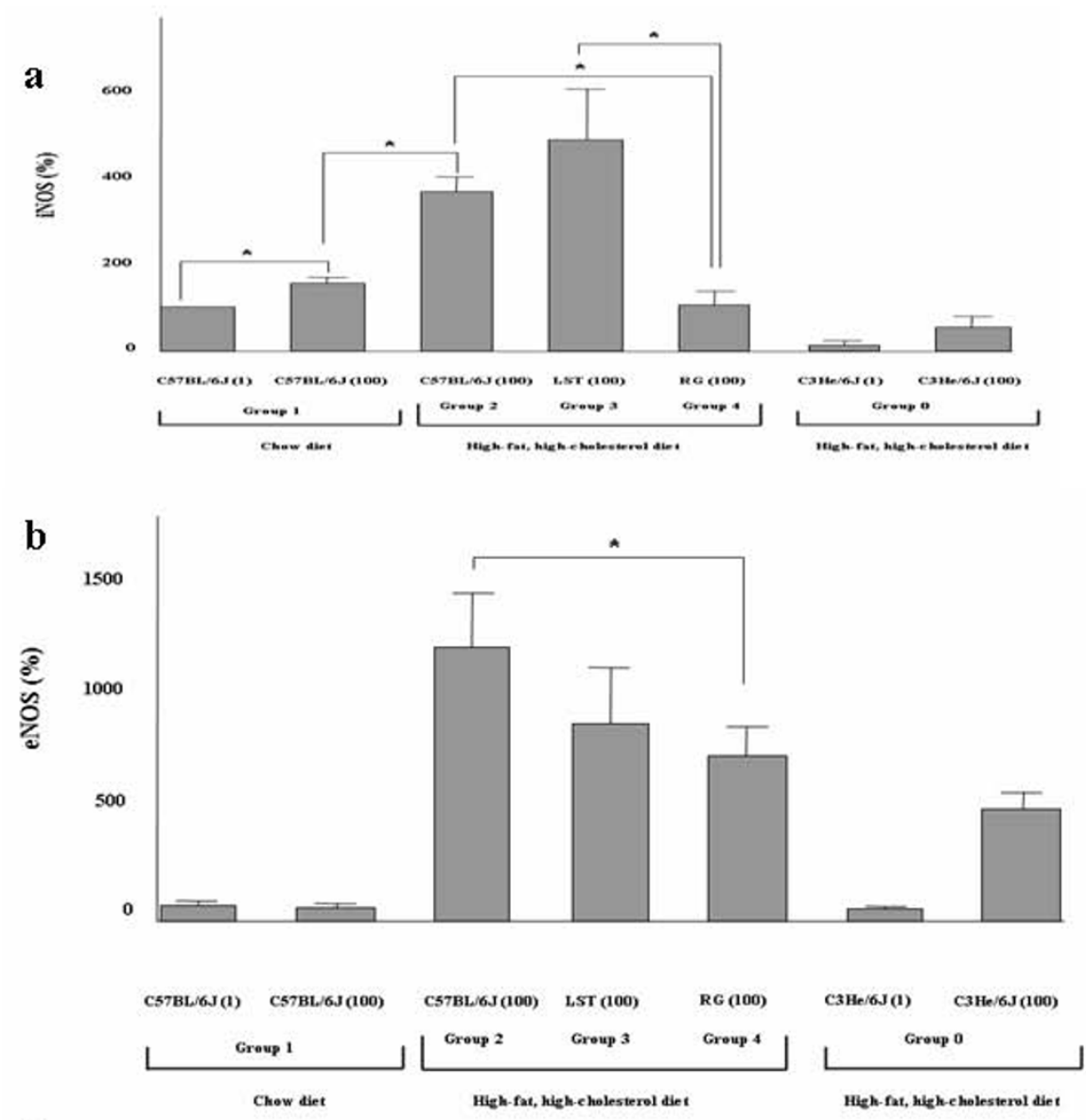

c

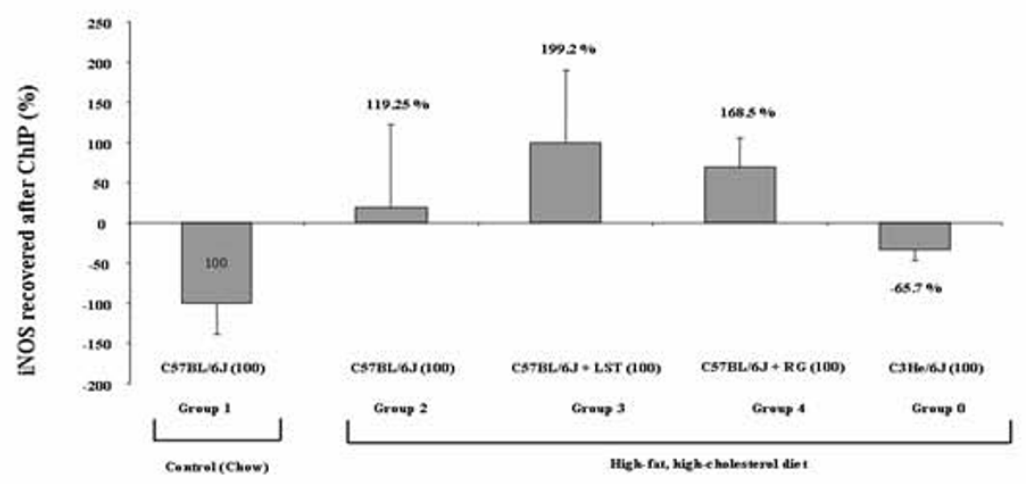

\section{Figure 5}

Treatments modified iNOS gene expression while PPAR $\gamma$-mediated iNOS amplification levels were similar. (a) iNOS mRNA relative expression in pooled liver samples from analyzed groups normalized to GAPDH expression. $* P<0.05$. (b) eNOS mRNA relative expression in pooled liver samples from analyzed groups normalized to GAPDH expression. Results are expressed as mean \pm SEM percentage of mean values obtained from equal numbers of $C 57 \mathrm{BL} / 6 \mathrm{~J}$ and $\mathrm{C} 3 \mathrm{He} / 6 \mathrm{~J} \mathrm{mice}$. *P < 0.05. (c) ChIP with a PPAR $\gamma$ antibody of study groups was used to amplify an iNOS promoter fragment. ChIP figures percentages indicate increments or decrements regarding C57BL/6J mice fed HFHC diet. Data of C57BL/6J mice fed chow diet was established as $100 \%$.

sion levels of the iNOS and IL- 6 genes were evaluated, we found lower expression levels in mice treated with RG with respect to those obtained in LST treated mice. Values reached significance for iNOS gene expression. Further enhancements of iNOS expression in mice that fed a HFHC diet treated with RG with respect to LST treated 
mice was not due to PPAR $\gamma$-mediated transcriptional activity as deduced from ChIP assays.

Because there is a second target of PPAR $\gamma$ activation, the liver $\mathrm{X}$ receptor $\alpha$ whose activity was not analyzed in our work, care must taken with the interpretation of our results. Nevertheless, we suggested possible additional antioxidants and anti-inflammatory effects of the RG that seem to be partially independent of its action on PPAR $\gamma$ activity. It is important to note that in our experimental model, we also observed a difference in the HDL-cholesterol concentration level. Values were higher in mice treated with RG compared to those found in the LST treated group. Besides the key role of HDL particles in the regulation of cholesterol homeostasis by enhancement reverse cholesterol transport, it is known that HDL also exhibits antioxidant and anti-inflammatory properties that participate in its general antiatherogenic effect. The antioxidant ability of HDL is due to the apoprotein moiety and to the presence of associated enzymes [47]. The apoA-I has also been shown to be capable of removing seeding molecules from LDL, thus preventing the oxidation of LDL-derived phospholipids $[38,48]$. Therefore we considered if this observed HDL increase would justify by itself the best antioxidant profile obtained in mice treated with RG as compared to LST treated mice. We showed that the HDL particles isolated from both treated animal groups exhibited similar characteristics regarding their capacity to avoid the oxidation of PACPC by HPODE. However, these experiments do not exclude the fact that perhaps this difference in the HDL levels could be relevant by itself. The determinant role of apo A-I in increasing HDL levels has been clearly established in apoE-knockout mice [49]. According to this, it could be possible that nonevaluated differences in apo A-I concentrations, and therefore differences in HDL concentrations and activities, were justified by other transcriptional regulators that were not analyzed in our work. Interestingly, because of the existence of a peroxisome proliferator-responsive element (PPRE) at the apo A-I gene, it also could be possible that as suggested [18] the apo A-I gene might be positively regulated by PPAR $\gamma$. This possibility was analyzed in our work. Thus, because we observed similar of PPAR $\gamma$-mediated apo A-I gene transcription we concluded that the apo A-I is certainly positively regulated by PPAR $\gamma$ agonists but also indirectly we concluded that the PPAR $\gamma$ activity was preserved in both treated animal groups.

The role of PPAR $\gamma$ as a transcriptional regulator of CD36 gene expression has been previously established $[9,17]$. Surprisingly, we observed a statistical difference in the relative expression levels of the CD36 gene between both treated animal groups while no difference was observed in the relative expression levels of PPAR $\gamma$-responsive gene SCARB1. Our results suggested differences at inflamma- tory and oxidative levels between both treated animal groups being less harmful in mice treated with RG than in mice treated with LST. Studies have demonstrated PPAR $\gamma$ induction in human monocytes following exposure to oxLDL $[9,50]$. Notably new evidence has been provided that Nrf2 plays an essential role in regulating CD36 expression $[18,21]$. Moreover, ox-LDLs are known to activate Nrf2-mediated gene responses [21]. Therefore, we thought that in our experimental model some similar situation would justify the observed difference in the CD36 gene relative expression levels where Nrf2 could be important. Thus, we performed gene expression analysis and ChIP experiments and concluded that in HFHC-fed mice treated with RG the smaller expression levels of the hepatic CD36 gene were observed as opposed to HFHCfed mice treated with LST because RG prevents Nrf2-mediated CD36 up-regulation. It has been reported that PPAR $\gamma$ ligands, 15-deoxy-Delta(12,14)-prostaglandin $J(2)$ (PGJ(2)), and troglitazone inhibits Nrf2-induced expression of the tromboxane synthase gene in macrophages [51]. Because Nrf2 also regulates CD36 gene expression, authors [21] suggested that the transcriptional regulators PPAR $\gamma$ and Nrf2 may interact functionally to modulate CD36 gene expression. As has been previously noted, we demonstrated similarly preserved PPAR $\gamma$ activity in hypercholesterolemic mice treated with RG or LST. Therefore we deduced that RG seems to afford some additional antiaterogenic properties that prevent Nrf2-depedent CD-36 up-regulation which are partially independent of its metabolizing properties as a PPAR $\gamma$ agonist.

We did not find statistically significant differences in the eNOS relative gene expression levels between treated groups with similarly preserved PPAR $\gamma$ activity. Authors suggest that TZDs protective effects on vascular wall cells are mediated by its ability to up-regulate eNOS gene expression $[52,53]$. This effect of TZDs may explain its in vivo vasodilating and blood pressure-lowering effects and, at least for some TZDs, seems to be independent of their PPAR $\gamma$ metabolizing effects. However, although the molecular mechanisms by which TZDs increase NO release are not completely worked out, they are likely to depend on each particular TZD. For example Troglitazone, has an alpha-tocopherol (vitamin E) moiety that is not present in other TZDs, and treatment of hepatocytes with vitamin $\mathrm{E}$ and Troglitazone but not with RG led to an inhibition of phosphoenolpyruvate carboxykinase gene expression suggesting a PPAR $\gamma$-independent, antioxidantrelated mechanism [54]. Goya et al [52] suggested that the antioxidant and anti-inflammatory properties observed following troglitazone administration to cells were linked to the 6-hydroxychromonanes structure of troglitazone. Jiang et al [55] proved that $\gamma$-tocopherol diminished prostaglandin E2 (PGE2) synthesis in macrophages. Therefore, some TZDs share common anti-inflammatory 
properties with PPAR $\gamma$ independency, which are partially mediated by its structural relations with tocols. Gonon et al [56] recently provide evidences that RG results in protection against myocardial contractile dysfunction induced by ischemia reperfusion in mice receiving RG by mediating eNOs protein phosphorilation without increasing total eNOS concentration.

Our work has concentrated in analyzing the hepatic expression of PPAR $\gamma$ and Nrf2 target genes and the valuation of some serum markers. Although it is important to go deep in the in vivo situation it is also important to recognize the differences of regulation of the expression of genes regulated by PPAR and Nrf2 are tissue [21] and context-dependent [57]. Thus, caution is required in the interpretation of our results. Particularly, further in vivo studies should be necessary to explore the role of Nrf2 transcription factor in modulating the progression of foam cell formation and atherosclerosis.

\section{Conclusion and Clinical Perspective}

The present study indicates that the administration of RG or LST to diet-induced atherosclerosis susceptible mice fed a HFHC diet preserves in both groups the PPAR $\gamma$ activity. RG seems to have antioxidant effects in addition to its main metabolic activity in a manner that actually diminishes rather than increases the expression of the gene CD36 by inhibiting its Nrf-2-dependent up-regulation. Despite the favourable effects of RG observed in this study, it must be acknowledged that the meta-analysis of Nissen et al [58] on RG and cardiovascular risk raises the hypothesis that TZDs treatments may increase the risk of myocardial infarction and cardiovascular events. However, the general consensus is that this hypothesis needs further evaluation [59]. Currently, animal and human studies suggest that PPAR $\gamma$ ligands have anti-inflammatory, antioxidant and vasculo-protective protective effects. However, though there are similarities in TZD-induced improvement in insulin sensitivity between experimental models and humans, there are also substantial differences. Studies have focused on the role of adipocytokines in metabolic control and their regulation by TZDs. Nevertheless, growing evidence suggests that the vasculo-protective effects of PPAR $\gamma$ ligands can be dissociated from its metabolizing actions. Thus, there may be important implications for the development of improved anti-atherogenic and antidiabetic drug treatments. Additionally, the identification of potential benefits associated with the common molecular structure among these drugs will have interesting clinical repercussions.

\section{Abbreviations}

$\mathrm{AT}_{1} \mathrm{R}=$ Angiotensin Type 1 Receptor; ChIP = Chromatin immunoprecipitation; eNOS (NOS3) = Nitric Oxide Synthase 3; HDL = High Density Lipoprotein; HFHC = high- fat high-cholesterol; IL-6 = Interleukin 6; iNOs (NOS2) = Nitric Oxide Synthase, inducible; LOOH = Lipid Hydroperoxide; LST = Losartan; NO = Nitric Oxide; Nrf2 = Nuclear Factor Erythroid 2-Like 2; PPAR $\gamma=$ Peroxisome Proliferator-Activated Receptor-Gamma; RG = Rosiglitazone.

\section{Acknowledgements}

This work was supported by grant Pl/06 from the Fundación Canaria de Investigación y Salud (FUNCIS) with an extension. Authors gratefully acknowledge the technical assistance of Erika Hernández Velazquez, Lidia Estupiñán-Quintana, Juan Verona and Clara Martel. We also thank Sarah Goldsmith for help on the English edition of the manuscript.

\section{References}

I. Ross R: Atherosclerosis--an inflammatory disease. N Engl J Med 1999, 340: II5-126.

2. Steinberg D: Low density lipoprotein oxidation and its pathobiological significance. J Biol Chem 1997, 272:20963-20966.

3. Davignon J, Ganz P: Role of endothelial dysfunction in atherosclerosis. Circulation 2004, 109:|II27-III32.

4. Chang MY, Olin KL, Tsoi C, Wight TN, Chait A: Human monocyte-derived macrophages secrete two forms of proteoglycan-macrophage colony-stimulating factor that differ in their ability to bind low density lipoproteins. J Biol Chem 1998, 273:15985-15992.

5. Nakashima Y, Fujii H, Sumiyoshi S, Wight TN, Sueishi K: Early human atherosclerosis: accumulation of lipid and proteoglycans in intimal thickenings followed by macrophage infiltration. Arterioscler Thromb Vasc Biol 2007, 27: I I59-1 I65.

6. Febbraio M, Hajjar DP, Silverstein RL: CD36: a class B scavenger receptor involved in angiogenesis, atherosclerosis, inflammation, and lipid metabolism. J Clin Invest 200I, 108:785-79I.

7. Febbraio M, Podrez EA, Smith JD, Hajjar DP, Hazen SL, Hoff HF, Sharma K, Silverstein RL: Targeted disruption of the class $B$ scavenger receptor CD36 protects against atherosclerotic lesion development in mice. J Clin Invest 2000, 105:1049-1056.

8. Barlic J, Zhang Y, Foley JF, Murphy PM: Oxidized lipid-driven chemokine receptor switch, CCR2 to CX3CRI, mediates adhesion of human macrophages to coronary artery smooth muscle cells through a peroxisome proliferator-activated receptor gamma-dependent pathway. Circulation 2006, I 1 4:807-819.

9. Nagy L, Tontonoz P, Alvarez JG, Chen H, Evans RM: Oxidized LDL regulates macrophage gene expression through ligand activation of PPARgamma. Cell 1998, 93:229-240.

10. Bagi Z, Koller A, Kaley G: PPARgamma activation, by reducing oxidative stress, increases NO bioavailability in coronary arterioles of mice with Type 2 diabetes. Am J Physiol Heart Circ Physiol 2004, 286:H742-H748.

II. Calkin AC, Forbes JM, Smith CM, Lassila M, Cooper ME, JandeleitDahm KA, Allen TJ: Rosiglitazone attenuates atherosclerosis in a model of insulin insufficiency independent of its metabolic effects. Arterioscler Thromb Vasc Biol 2005, 25:1903-1909.

12. Crosby MB, Svenson JL, Zhang J, Nicol CJ, Gonzalez FJ, Gilkeson GS: Peroxisome proliferation-activated receptor (PPAR)gamma is not necessary for synthetic PPARgamma agonist inhibition of inducible nitric-oxide synthase and nitric oxide. J Pharmacol Exp Ther 2005, 3 I 2:69-76.

13. Shinohara E, Kihara S, Ouchi N, Funahashi T, Nakamura T, Yamashita $S$, Kameda-Takemura K, Matsuzawa Y: Troglitazone suppresses intimal formation following balloon injury in insulin-resistant Zucker fatty rats. Atherosclerosis 1998, 136:275-279.

14. Jiang C, Ting AT, Seed B: PPAR-gamma agonists inhibit production of monocyte inflammatory cytokines. Nature 1998, $391: 82-86$.

15. Ricote M, Li AC, Willson TM, Kelly CJ, Glass CK: The peroxisome proliferator-activated receptor-gamma is a negative regulator of macrophage activation. Nature 1998, 39 I:79-82.

16. Pasceri V, Wu HD, Willerson JT, Yeh ET: Modulation of vascular inflammation in vitro and in vivo by peroxisome proliferator- 
activated receptor-gamma activators. Circulation 2000, 101:235-238.

17. Chawla A, Barak Y, Nagy L, Liao D, Tontonoz P, Evans RM: PPARgamma dependent and independent effects on macrophagegene expression in lipid metabolism and inflammation. Nat Med 2001 ,

$7: 48-52$

18. Chen Z, Ishibashi S, Perrey S, Osuga J, Gotoda T, Kitamine T, Tamura Y, Okazaki H, Yahagi N, lizuka Y, Shionoiri F, Ohashi K, Harada K, Shimano H, Nagai R, Yamada N: Troglitazone inhibits atherosclerosis in apolipoprotein E-knockout mice: pleiotropic effects on CD36 expression and HDL. Arterioscler Thromb Vasc Biol 200I, 21:372-377.

19. Li AC, Brown KK, Silvestre MJ, Willson TM, Palinski W, Glass CK: Peroxisome proliferator-activated receptor gamma ligands inhibit development of atherosclerosis in LDL receptor-deficient mice. J Clin Invest 2000, 106:523-53I.

20. Tao L, Liu HR, Gao E, Teng ZP, Lopez BL, Christopher TA, Ma XL, Batinic-Haberle I, Willette RN, Ohlstein EH, Yue TL: Antioxidative, antinitrative, and vasculoprotective effects of a peroxisome proliferator-activated receptor-gamma agonist in hypercholesterolemia. Circulation 2003, 108:2805-28II.

21. Ishii T, Itoh K, Ruiz E, Leake DS, Unoki H, Yamamoto M, Mann GE: Role of Nrf2 in the regulation of CD36 and stress protein expression in murine macrophages: activation by oxidatively modified LDL and 4-hydroxynonenal. Circ Res 2004, 94:609-616.

22. Hosono T, Mizuguchi H, Katayama K, Koizumi N, Kawabata K, Yamaguchi T, Nakagawa S, Watanabe Y, Mayumi T, Hayakawa T: RNA interference of PPARgamma using fiber-modified adenovirus vector efficiently suppresses preadipocyte-to-adipocyte differentiation in 3T3-LI cells. Gene 2005, 348:157-165.

23. Sharma AM, Janke J, Gorzelniak K, Engeli S, Luft FC: Angiotensin blockade prevents type 2 diabetes by formation of fat cells. Hypertension 2002, 40:609-6II.

24. Janke J, Engeli S, Gorzelniak K, Luft FC, Sharma AM: Mature adipocytes inhibit in vitro differentiation of human preadipocytes via angiotensin type I receptors. Diabetes 2002, 5I:1699-I707.

25. Schupp M, Janke J, Clasen R, Unger T, Kintscher U: Angiotensin type I receptor blockers induce peroxisome proliferatoractivated receptor-gamma activity. Circulation 2004, 109:2054-2057.

26. Benson SC, Pershadsingh $\mathrm{HA}, \mathrm{Ho} C l$, Chittiboyina A, Desai $P$, Pravenec M, Qi N, Wang J, Avery MA, Kurtz TW: Identification of telmisartan as a unique angiotensin II receptor antagonist with selective PPARgamma-modulating activity. Hypertension 2004, 43:993-1002.

27. Sugawara A, Takeuchi K, Uruno A, Ikeda Y, Arima S, Kudo M, Sato K Taniyama $Y$, Ito $S$ : Transcriptional suppression of type $I$ angiotensin II receptor gene expression by peroxisome proliferator-activated receptor-gamma in vascular smooth muscle cells. Endocrinology 200I, I 42:3 I25-3|34.

28. Jones JR, Barrick C, Kim KA, Lindner J, Blondeau B, Fujimoto Y, Shiota M, Kesterson RA, Kahn BB, Magnuson MA: Deletion of PPARgamma in adipose tissues of mice protects against high fat diet-induced obesity and insulin resistance. Proc Natl Acad Sci U S A 2005, 102:6207-62I2.

29. Vidal-Puig A, Jimenez-Linan M, Lowell BB, Hamann A, Hu E, Spiegelman B, Flier JS, Moller DE: Regulation of PPAR gamma gene expression by nutrition and obesity in rodents. I Clin lnvest 1996, 97:2553-2561.

30. Han J, Hajjar DP, Zhou X, Gotto AM Jr., Nicholson AC: Regulation of peroxisome proliferator-activated receptor-gammamediated gene expression. A new mechanism of action for high density lipoprotein. J Biol Chem 2002, 277:23582-23586.

31. Zhang B, Berger J, Zhou G, Elbrecht A, Biswas S, White-Carrington $\mathrm{S}$, Szalkowski D, Moller DE: Insulin- and mitogen-activated protein kinase-mediated phosphorylation and activation of peroxisome proliferator-activated receptor gamma. I Biol Chem 1996, 27I:3 I77|-31774.

32. Diradourian C, Girard J, Pegorier JP: Phosphorylation of PPARs: from molecular characterization to physiological relevance. Biochimie 2005, 87:33-38.

33. Nourooz-Zadeh J, Tajaddini-Sarmadi J, Ling KL, Wolff SP: Low-density lipoprotein is the major carrier of lipid hydroperoxides in plasma. Relevance to determination of total plasma lipid hydroperoxide concentrations. Biochem $\rfloor 1996,313$ ( $\mathbf{P t}$ 3):78I-786.

34. Auerbach BJ, Kiely JS, Cornicelli JA: A spectrophotometric microtiter-based assay for the detection of hydroperoxy derivatives of linoleic acid. Anal Biochem 1992, 20 I:375-380.

35. Garin MC, James RW, Dussoix P, Blanche H, Passa P, Froguel P, Ruiz J: Paraoxonase polymorphism Met-Leu54 is associated with modified serum concentrations of the enzyme. A possible link between the paraoxonase gene and increased risk of cardiovascular disease in diabetes. J Clin Invest 1997, 99:62-6.

36. Mackness B, Mackness MI, Arrol S, Turkie W, Durrington PN: Effect of the human serum paraoxonase 55 and 192 genetic polymorphisms on the protection by high density lipoprotein against low density lipoprotein oxidative modification. FEBS Lett 1998, 423:57-60.

37. Navab M, Hama SY, Hough GP, Subbanagounder G, Reddy ST, Fogelman AM: A cell-free assay for detecting HDL that is dysfunctional in preventing the formation of or inactivating oxidized phospholipids. J Lipid Res 200I, 42:I308-I317.

38. Navab M, Hama SY, Anantharamaiah GM, Hassan K, Hough GP, Watson AD, Reddy ST, Sevanian A, Fonarow GC, Fogelman AM: Normal high density lipoprotein inhibits three steps in the formation of mildly oxidized low density lipoprotein: steps 2 and 3. J Lipid Res 2000, 4I: I495-I508.

39. Ramirez-Zacarias JL, Castro-Munozledo F, Kuri-Harcuch W: Quantitation of adipose conversion and triglycerides by staining intracytoplasmic lipids with Oil red O. Histochemistry 1992, 97:493-497.

40. Furukawa S, Fujita T, Shimabukuro M, Iwaki M, Yamada Y, Nakajima Y, Nakayama O, Makishima M, Matsuda M, Shimomura I: Increased oxidative stress in obesity and its impact on metabolic syndrome. J Clin Invest 2004, I | 4: 1752- I76I.

4I. Rubin J, Murphy TC, Zhu L, Roy E, Nanes MS, Fan X: Mechanical strain differentially regulates endothelial nitric-oxide synthase and receptor activator of nuclear kappa B ligand expression via ERKI/2 MAPK. I Biol Chem 2003, 278:340I8-34025.

42. Rozen S, Skaletsky H: Primer3 on the WWW for general users and for biologist programmers. Methods Mol Biol 2000, 132:365-386.

43. Crosby MB, Svenson J, Gilkeson GS, Nowling TK: A novel PPAR response element in the murine iNOS promoter. Mol Immunol 2005, 42: I303-1310.

44. Sato O, Kuriki C, Fukui Y, Motojima K: Dual promoter structure of mouse and human fatty acid translocase/CD36 genes and unique transcriptional activation by peroxisome proliferator-activated receptor alpha and gamma ligands. $J$ Biol Chem 2002, 277:|5703-I57|I.

45. Teboul L, Febbraio M, Gaillard D, Amri EZ, Silverstein R, Grimaldi PA Structural and functional characterization of the mouse fatty acid translocase promoter: activation during adipose differentiation. Biochem J 200I, 360:305-312

46. Hsueh WA, Bruemmer D: Peroxisome proliferator-activated receptor gamma: implications for cardiovascular disease. Hypertension 2004, 43:297-305.

47. Navab M, Ananthramaiah GM, Reddy ST, Van Lenten BJ, Ansell BJ, Fonarow GC, Vahabzadeh K, Hama S, Hough G, Kamranpour N, Berliner JA, Lusis AJ, Fogelman AM: The oxidation hypothesis of atherogenesis: the role of oxidized phospholipids and HDL. J Lipid Res 2004, 45:993-1007.

48. Navab M, Hama SY, Cooke C], Anantharamaiah GM, Chaddha M, Jin L, Subbanagounder G, Faull KF, Reddy ST, Miller NE, Fogelman AM: Normal high density lipoprotein inhibits three steps in the formation of mildly oxidized low density lipoprotein: step I. J Lipid Res 2000, 4 I : I 48I-I 494

49. Paszty C, Maeda N, Verstuyft J, Rubin EM: Apolipoprotein Al transgene corrects apolipoprotein $E$ deficiency-induced atherosclerosis in mice. J Clin Invest 1994, 94:899-903.

50. Tontonoz P, Nagy L, Alvarez JG, Thomazy VA, Evans RM: PPARgamma promotes monocyte/macrophage differentiation and uptake of oxidized LDL. Cell I998, 93:24I-252.

5I. Ikeda Y, Sugawara A, Taniyama Y, Uruno A, Igarashi K, Arima S, Ito S, Takeuchi K: Suppression of rat thromboxane synthase gene transcription by peroxisome proliferator-activated receptor gamma in macrophages via an interaction with NRF2. I Biol Chem 2000, 275:33i42-33।50. 
52. Goya K, Sumitani S, Otsuki M, Xu X, Yamamoto H, Kurebayashi S, Saito H, Kouhara H, Kasayama S: The thiazolidinedione drug troglitazone up-regulates nitric oxide synthase expression in vascular endothelial cells. J Diabetes Complications 2006, 20:336-342.

53. Polikandriotis JA, Mazzella LJ, Rupnow HL, Hart CM: Peroxisome proliferator-activated receptor gamma ligands stimulate endothelial nitric oxide production through distinct peroxisome proliferator-activated receptor gamma-dependent mechanisms. Arterioscler Thromb Vasc Biol 2005, 25:1810-1816.

54. Davies GF, Khandelwal RL, Wu L, Juurlink BH, Roesler WJ: Inhibition of phosphoenolpyruvate carboxykinase (PEPCK) gene expression by troglitazone: a peroxisome proliferator-activated receptor-gamma (PPARgamma)-independent, antioxidant-related mechanism. Biochem Pharmacol 200I, 62:107I-1079.

55. Jiang Q, Elson-Schwab I, Courtemanche C, Ames BN: gamma-tocopherol and its major metabolite, in contrast to alpha-tocopherol, inhibit cyclooxygenase activity in macrophages and epithelial cells. Proc Natl Acad Sci U S A 2000, 97: | | 494- I | 499.

56. Gonon AT, Bulhak A, Labruto F, Sjoquist PO, Pernow J: Cardioprotection mediated by rosiglitazone, a peroxisome proliferator-activated receptor gamma ligand, in relation to nitric oxide. Basic Res Cardiol 2007, 102:80-89.

57. Kavanagh IC, Symes CE, Renaudin P, Nova E, Mesa MD, Boukouvalas G, Leake DS, Yaqoob P: Degree of oxidation of low density lipoprotein affects expression of CD36 and PPARgamma, but not cytokine production, by human monocyte-macrophages. Atherosclerosis 2003, 168:27I-282.

58. Nissen SE, Wolski K: Effect of rosiglitazone on the risk of myocardial infarction and death from cardiovascular causes. $N$ Engl J Med 2007, 356:2457-247I.

59. Rosen CJ: The rosiglitazone story--lessons from an FDA Advisory Committee meeting. N Engl J Med 2007, 357:844-846.

\section{Publish with Biomed Central and every scientist can read your work free of charge}

"BioMed Central will be the most significant development for disseminating the results of biomedical research in our lifetime. "

Sir Paul Nurse, Cancer Research UK

Your research papers will be:

- available free of charge to the entire biomedical community

- peer reviewed and published immediately upon acceptance

- cited in PubMed and archived on PubMed Central

- yours - you keep the copyright

Submit your manuscript here:

http://www.biomedcentral.com/info/publishing_adv.asp
BiolMedcentral 